\title{
On Status Quo of Ethnic Music and Its Function in Contemporary Society
}

\author{
Wenmin Zhong \\ Music and Dance Institute \\ Qujing Normal University \\ Qujing, Yunnan, China 655011
}

\begin{abstract}
Originated in Chinese mainland, Chinese ethnic music with Chinese characters was created by all Chinese ethnic groups. It originated from and is spread among folks, and it is a very special artistic expression form in China's even the world's music and art history. Chinese nationality has a long history, and a lot of excellent works have important historical significance and values. With the transformation and development of society, more and more youths have a special liking for pop music, meanwhile neglect ethnic music. To help more Chinese people understand the connotations of Chinese ethnic music, we should dig into historical values of ethnic music, and this is the best way to inherit our national culture. Based on the further research of ethnic music, this paper will elaborate on its relationship with ethnic culture.
\end{abstract}

Keywords-ethnic music; ethnic features; national culture; close relationships

\section{INTRODUCTION}

Ethnic music is a miracle in all Chinese music. It is an important carrier and another expression form of traditional Chinese culture. China is a large and multi-ethnic country; so, different regions and nationalities have their own unique musical styles. In western China, their music might be sonorous, while in eastern China, their music is probably tender and lyric. It is obvious that the contents and forms of Chinese ethnic music are diversified. However, the status quo of ethnic music is that it is being battered, which has indirect far-reaching impact on our national culture. It is worth exploring the development and relationships between ethnic music and culture.

\section{THE DEVELOPMENT AND FEATURES OF ETHNIC MUSIC}

\section{A. Development Tendency of Ethnic Music}

With the increasing of productivity, people's living standards were also upturning. Zhou Dynasty (1046B.C.256B.C.) was the first peak time for the development of Chinese ethnic music. The ancient rulers highly valued music, even they wanted to govern the country and educate the people by music and rites. It can be seen that the concept of "music and rite governance" was deep rooted in people's mind; in addition, the social environment also propelled the development of ethnic music.
From Wei and Jin Dynasties to Sui and Tang Dynasties (220 A.D.-907A.D.), Chinese music has changed greatly. Especially in Sui and Tang Dynasties, Chinese music became mature and new musical styles were explored, and they were very typical in Chinese history. Ming and Qing Dynasties were the third phase to develop Chinese music. At that time, ethnic music had not come into being yet; what prevailed was still opera, which promoted the development of ethnic music in sequent decades.

Nowadays, the ethnic music that we are listening to actually appeared at the end of Ming Dynasty. At that time, cultural exchanges between China and Western countries were frequent; therefore, our ethnic music had Western features. Under specific circumstances, ethnic music once inspired Chinese people and became a spiritual support.

\section{B. Manifestation of Ethnic Music}

Ethnic music has its uniqueness no matter in singing technique or tone; it is based on pentatonic mode, i.e. 1, 2, 3, 5, 6 in modern music score. For example, a popular and representative ethnic music, Jasmine, originated from Yangzhou, represents people's love for life and beauty. It is also a heavy load of Yangzhou's culture and history. Little Running River is an ethnic music of Yunnan Province, presenting the vigor and purity of maiden. With its soft, exquisite, lyric and romantic features, people are absorbed in the beauty of the song. Since it was developed in south western Yunnan, a mysterious fertile land with humanistic features, the song possesses such a charm.

\section{Singing Forms of Ethnic Music}

China has 56 ethnic groups, and each of them has its own languages, customs and religious beliefs. Under such a circumstance, they have different ethnic music and singing style and conquer the public with their unique singing forms. Once it was regarded as the professional ethnic singing style, which is distinctive in Chinese vocal music art. Ethnic singing style is greatly different from popular singing styles; it requires that the singer's voice must be clear and sweet. Its language is not necessary to be exquisite but vivid, expressing people's real and pure emotions. Recent years, Chinese people come to realize the significance to protect ethnic music and actually they have taken action, especially in exploiting and protecting 
the ethnic singers. Only through them can ethnic music possibly be inherited from generation to generation.

\section{Combination of ethnic music and dance}

Ethnic music, as a part of traditional Chinese music was never alone in history. It was always associated with graceful dance and meaningful poems. Until now, we can see many minority compatriots, especially Mongolian and Tibetan folks; when they are singing ethnic music, they also dance and play Morinhuur at the same time. This kind of ethnic music is very regional, and it helps more people have a better understanding of minorities' culture.

\section{E. Media of Ethnic Music}

In various art forms, ethnic music is accompanied with the development of human society, and it is an inevitable outcome of human history. Ethnic music is a miracle of traditional Chinese culture, is the embodiment of the wisdom of working people. In those undeveloped years, the only way to help ethnic music survive is to pass from mouth to mouth. This traditional medium also contributes to the natural beauty and simplicity of ethnic music.

\section{The Status QuO OF ETHNIC Music}

\section{A. The Influence of External Environment}

Most ethnic music was created in minority regions, especially in the southwest and northwest of China. Since Chinese economic structure is unbalanced and western China is respectively undeveloped, the environment for ethnic music creation is so harsh that a lot of splendid ethnic music for various reasons was nipped in the bud. The worsening of external environment results in the low creativity of ethnic music.

Meanwhile, ethnic music lacks national financial supports, which also causes the loss of excellent ethnic music. Many people were endowed with musical talent, but they had to quit their musical career because of the environment.

\section{B. The Shock of Foreign Culture}

Booming and prosperity of the times bring about frequent communications among ethnic groups. At the same time, people's aesthetic consciousness is also improving. Diversified musical forms have marginalized Chinese ethnic music; it mainly manifests that youths are not interested in ethnic music at all, not willing to understand it either. This is a predicament and potential crisis for the inheritance of Chinese ethnic music.

\section{Too Much Commercial Atmosphere}

Pop music is the outcome of market economy; its operation mode complies with the law of market economy development. Being the product of market, pop music can meet the needs of most music-lover. Since it was born in industrial chain, pop music can always lead the fashion. However, no matter in terms of lyrics or music, ethnic music lags far behind the development of times, even is on the opposite of youths' pursuit. Also its monotonous pattern of performance cannot draw the attention of those curious young people.

\section{Not Catering to the Youths}

At present, the audience of music has a tendency of youthorientation. There is a huge gap between pop and ethnic music. Students are the leading active factor in musical art, young and ignorant. Pop music is popular because it has strong features of times and resonates to modern people. Yet, ethnic music at least cannot emotionally pander to youths' thoughts.

\section{Solutions OF Protecting Ethnic Music}

\section{A. State Financial Support}

The prosperity of ethnic music cannot solely rely on individual's efforts, but also state or government's financial support. For example, to build a museum in the birthplace of ethnic music, then the sheet music of different historical periods or instruments of same periods can be collected for exhibition. In that way more people can realize the charm of ethnic music; it is a good way for ethnic music protection.

Holding an ethnic music object exhibition, with different types of minorities' instruments, musical costumes and props which have values of researching and collecting, is a great opportunity for more people to approach ethnic music and arouse their interest for ethnic music. It is of great help for the spread and development of ethnic music culture.

\section{B. Cultivation of Ethnic Musicians}

Ethnic music is an effective approach to inherit and develop traditional Chinese culture, cultivate individual's humanistic qualities and enrich spiritual world. Actually there are a lot of ethnic musicians. Due to objective factors they could not make breakthrough in ethnic music creation. Therefore, to succeed Chinese ethnic musical culture, Chinese government should set up a fund to cultivate ethnic musicians and help them further their ethnic music creation.

\section{Offering A Bigger Stage}

We are now living in a materially abundant era, and when it develops to a certain degree, spiritual culture correspondingly come into being. More and more people have a special liking for entertaining artistic expression forms. Although ethnic music is not to entertain the mass, it can rely on them to spread its thoughts and culture and make more people understand its unknown features. Thus, some variety shows should provide a stage for ethnic music because it is everyone's obligation to inherit and develop Chinese ethnic culture.

\section{RELATIONSHIPS BETWEEN ETHNIC MUSIC AND CULTURE}

\section{A. Ethnic Music Propels the Construction of Ethnic Culture}

In order to disseminate ethnic music throughout the state, ethnic music must rely on ethnic culture because they complement each other. China has a 5,000-year history, in which different music of different eras were vigorous and had obvious guiding function to Chinese society and culture. For instance, in The Book of Songs, many beautiful poems were 
widespread, which had a far-reaching impact on society of the time.

Recent years, with the presence of original ethnic music in many variety shows, its natural and unsophisticated features are warmly welcomed by the public. More people have opportunities to touch the charm of ethnic music; meanwhile, it indirectly promotes the ethnic cultural construction of China. Only when ethnic music is closely associated with ethnic culture can ethnic music and ethnic cultural construction of China move forward.

\section{B. Ethnic Culture Propels the Development of Ethnic Music}

Ethnic music creation requires specific environments and conditions, and the best fertile soil is the culture and history of where it originated from. Most ethnic music was produced in western China and a lot of minority compatriots are gathering there. It is well-known that minority regions are characterized by abundant languages, unique culture and different customs, which create conditions for ethnic music. Therefore, to some degree, the development and prosperity of ethnic music cannot be separated from the long history and culture of the ethnic group.

\section{Ethnic Music and Culture Fuse with One Another}

Ethnic music reflects the features of ethnic groups, and in turn, ethnic culture is the foundation of ethnic music. Actually, the relationships between ethnic music and culture are subtle. They are seemingly independent and irrelevant, but also inseparable. Ethnic music lacking ethnic culture will not touch the audiences and the whole ethnic group becomes lifeless. Without a transmission channel, ethnic culture will go extinct in endless historical flow. Likewise, ethnic music without cultural connotations is destined to perish.

\section{Ethnic Music and Culture Are the Fruits of the Times}

When ethnic culture develops to a certain phase, it needs some spiritual contents to support itself. Under such a circumstance, ethnic music came into being. For further development, ethnic culture requires more interesting real objectives for supplement. It is should be clarified that as an important part of ethnic culture, the significance of ethnic music is not only to inherit ethnic culture, but also highlight national identity and propagate national spirit. Some modern elements should inevitably be added to ethnic music. Only in that way can ethnic music adapt to the development of society and cater to the public's appetite. In contemporary society, no open ethnic groups are restricted in a narrow development space, and this has become the tendency of the times.

\section{THE FAR-REACHING SignifICANCE OF ETHNIC MusiC}

\section{A. Mirroring Social Life}

After thousands of years of development, Chinese ethnic music has accumulated artistic wisdoms and creation talents of all ethnic groups, gifted with distinct ethnic characters. Constant fusion and exchanges among all ethnic groups make Chinese ethnic music shine among today's art forms. Ethnic music was created by all working people in their long-term toiling. It reflected ordinary people's real life. Sometimes, people even can find the trace and clues of those working people in extant ethnic music, by which the appearance of ethnic music in history also can be seen.

\section{B. Cultivating Individual's Sentiment of Humanity}

Although ethnic music is just a form of musical expression, it also contains a lot of emotions and distinctive national characters. Being the priceless miracle of Chinese cultural treasure, it shows the characteristics, psychology and aesthetic values of an ethnic group, symbolizes Chinese national spirit as well. Long engagement with ethnic music can intangibly promote individual's aesthetic and gradually becomes the ideological prop in one's life.

\section{Being A Window to Comprehend Chinese Ethnic Culture}

There are a lot of minorities in China. Among them Yi nationality is a concentrated minority with a relatively large population. Every year they will celebrate the Torch Festival which has a long history. Dancing and singing show their expectation for happy life. By the songs they sing, you can find the uniqueness of their ethnic culture. A lot of scholars regret that ethnic music has gradually been forgotten in their development. Thanks to some musicians' perseverance, the ethnic music that has been preserved and inherited exceptionally has tough vitality. Now, people focus on ethnic music again because they want to have a better understanding of traditional Chinese culture.

\section{CONCLUSION}

During the long-term development, Ethnic music has fused other ethnic groups' wisdom and talent and eventually becomes a musical art with its own national features. Although the history of ethnic groups has already been dim, these artistic treasures are preserved. However, in such a quick-transition society, if people want to keep the development of ethnic music, they should not only absorb the essence and discard the dross, but also blend it into ethnic culture. Provided that ethnic music is ignored by the public, it can never be inherited and develop, and traditional Chinese cultural loss will be worsening. On the basis of full research and taking over ethnic cultural memory, ethnic culture can take into good effect in world's cultural setup. To strengthen the expressive force of ethnic music is the key factor to enhance the level Chinese ethnic music. How to succeed and develop ethnic music and culture is a thoughtful subject.

\section{REFERENCES}

[1] Ma Dongya. Contemporary Music of Hui Nationality [M]. Ningxia People's Publishing House. 2013. 08.

[2] Rao Wenxin. World's Ethnic Music and Culture [M]. Shanghai Music Publishing House. 2007. 09.

[3] Liang Yiru. On Ethnic Aesthetic Culture [M]. Communication University of China Press. 2007. 03. 